\title{
LINGUISTIC SIGNS IN SLANG LANGUAGE USED IN DRUG TRADING TRANSACTIONS IN PADANG CITY
}

\author{
Amelia Yuli Astuti ${ }^{1 *}$; Bram Denafri ${ }^{2}$ \\ ${ }^{1}$ English Department, Faculty of Literature, Ekasakti University \\ Jl. Veteran Dalam No. 26B, Padang Pasir, Sumatera Barat 25113, Indonesia \\ ${ }^{2}$ Indonesian Department, Faculty of Letter, Pamulang University \\ Kampus UNPAM 2, Building B, Floor $5^{\text {th }}$. Jl. Raya Puspitek, Serpong, Banten 15310, Indonesia \\ 'ameliayuli127@gmail.com; 2bram@unpam.ac.id
}

Received: $22^{\text {nd }}$ July 2020/Revised: $10^{\text {th }}$ August 2020/Accepted: $09^{\text {th }}$ September 2020

How to Cite: Astuti, A. Y. \& Denafri, B. (2020). Linguistic signs in slang language used in drug trading transactions in Padang city. Lingua Cultura, 14(2), 203-210. https://doi.org/10.21512/lc.v14i2.6588

\begin{abstract}
The research discussed the linguistic sign in slang language used in drug transactions. Slang language was found based on interviews conducted with drug dealers and drug users in Ranah Parak Rumbio, South Padang subdistrict, Padang City. The aim of the research was to determine the signifier and signified found in drug slang language. Furthermore, the research determined the order of signification by analyzing the meaning of slang language based on its context. The data were obtained using the direct observation method. This was achieved by using interview techniques. The interviews were conducted with three informants. There were two men who used to be drug dealers and former drug users, and a woman who was an observer and anti-drug activist. Furthermore, the data were analyzed by using equalizing and differentiation techniques. Data analysis was carried out using semiotic by referring to the linguistic signs theory proposed by Saussure and the theory of order of signification by Barthes. In conclusion, it is found that slang is formed in word categories, abbreviations, and phrases. Then, the factors of language are also considered, such as time and place of the background, the number of participants in the interaction, talking topic, and interaction function. These factors then determine the use of slang terms between drug users and dealers.
\end{abstract}

Keywords: linguistic signs, language used, drug trading language

\section{INTRODUCTION}

Language has its own uniqueness which can be found in various types of community groups. A community agrees on a certain language understood by them. Understanding a language that can only be interpreted by a certain community group is called slang. Slang is said to be a social variation that is used in special ways and also confidential. It refers to a language that is only used by a limited group of people and is unknown to other communities. The community believes that the slang language would create security and confidentiality.

Language is a tool by humans to represent something. Without language being present, we as humans cannot communicate. Language has been formed since humans existed. Indonesians presumably perceive bahasa Indonesia as the mother tongue.
Mother tongue is the language that is first used by our parents today, which is used as an everyday language. This mother-tongue then becomes the means of communication.

Indonesians also speak formal and foreign languages. In addition to this, it is also known Indonesian as the nation's unifying language. On the other hand, Indonesians also speak foreign languages when communicating with the outside world. By learning foreign languages, people are able to participate in the trends of the times and experience the latest technology. Besides, people also use foreign languages to interpret something that is called a discourse. Discourse is a communication process that uses symbols related to interpretations and events in the community (Sari, 2018).

According to Devianty (2017), language is a gift given by God. The use of language also 
distinguishes between humans and animals. The language used by humans can be explained morphologically, phonologically, and meaningfully. On the other hand, the language used by animals is only consisted of sounds and is the instinct of these animals to communicate. Hence, it cannot be studied in morphological, phonological, and meaning forms. It can only be understood by logic and perceive the sound using letters. Language is a brain process with human speech devices. The brain process also affects the vocabulary that will expose (Anisah, 2019). Language is also formed due to habits in everyday life. Since childhood, people imitate what is done and said by their parents and the people around them. Therefore, language formation is primarily affected by the people closest to it (Noermanzah, 2019).

The research discusses how language use is influencing the people in a drugs-particular group. Drug users and dealers create secret groups or communities in a large number, and they have a web of networks throughout the country. To not disclose their identity, they use special codes while naming the types of drugs, dealing with transactions, and getting people involved in the distribution. This is considering the distribution of drugs, which has spread all over the country (Hariyanto, 2018). It is happening not only in the capital cities but also in remote villages. This explains why the government still is unable to control the use of narcotics as it is effortless to conduct drug transactions in the villages.

Drug eradication is indeed not easy. Despite the efforts made by the police and the government to eradicate illegal drug use, however, it still is a work in progress. The threat of drugs does not only come at the national level but also from other countries. In overseas, there are many types of drugs that existed, but the news that is heard is only about circulation in Indonesia. The drug network has impacted the younger generation (Setyawan \& Sulistyawati, 2019). According to Setyawan and Sulistyawati (2019), the east coast of Sumatra is the most vulnerable area for drug trafficking as there are many ports of entry for drugs coming from abroad. Such similar cases need to be resolved through the root. Besides, drug abuse is considered a national and international problem (Suyatna, 2018).

However, Indonesia has faced problems related to drug addiction. It is not only opium for drugs but also opium for adhesive. The strong smell in some adhesive brands, such as Fox, makes people abuse it. They smell it for a long time, opium with the adhesive smell (Fadli \& Suwandewi, 2019). Fadli and Suwandewi explain that young people who are addicted to opium abuse the adhesive smell that is considered a trend. This could pose a threat to today's young generation.

In the research, the focus of the community groups using slang language is the drug dealers. The slang language is used as a communication means that consisted of a set of codes in drug dealing transactions. As a result, the case of drug spread is quite alarming. The research aims to determine linguistic signs found in the language and codes the drug dealers and drug users use while performing transactions. The code and language used are not common to the general public. Therefore, the research aims to seek the relationship between linguistic signs, the process of language formation, as well as its context. Understanding the slang language spoken in drug trafficking organizations will enable them to identify drug abuse signs that can threaten people. This understanding can also provide treatment or assistance for those in need of help.

The research questions the process of forming slang language in the informants' speech. It also observes the lingual signs in slang language and the factors influencing the drug users to use slang language. The research's objective is to determine the language formation process in slang language used in drug trafficking organizations. The data were collected from the informants' utterances, a description of the lingual signs in the slang language, and the factors influencing the drug users' actions and communications.

The research discusses the linguistic sign in the slang language used in drug trafficking organizations by using the linguistic sign theory proposed by Saussure in Chandler (2017). The data will provide results in the concept of signs, connotation, and denotation meanings. According to Saussure (in Chandler, 2017), the linguistic sign is not a relationship between a thing and a name, but preferably between the concept and the sound patterns. The signified are concepts, while the sound patterns are signifiers. The intended sign pattern is not delivering its actual meaning, but one that has a physical form. Therefore, a thought pattern is formed in the brain, resulting in the creation of an image or object. The object description language is called a linguistic sign which is associated with a concept.

There are several slang languages found in many drug trafficking organizations in this research, with many opportunities while examining linguistic signs in various slang languages. The problem posed in this research is to determine linguistic signs found in various slang languages used by the drug dealers. Furthermore, this research aims to discuss the concept of signs as proposed by Saussure in Chandler (2017) and discover its connotation and denotation meanings. Signs can be formed from words, images, sounds, tastes, or objects, but it does not have intrinsic meaning. These concepts will only become signs if it is embedded with meaning.

Previous research on linguistic signs has certainly been carried out. The research tries to seek a different angle by taking the data which is based on language phenomenon. In particular, it discusses the slang language variety that is associated with drug trading transactions. Also, the research analyzes the connotation and denotation meanings. The previous research about signs examines the meaning of Honda advertisement (ad) through linguistic and visual signs (Kinanthi \& Nugroho, 2017). The Honda ad examined is a car ad with the free sub-brand in the form of images and footage in the ad. The research discusses 
the meaning of the visual and linguistic signs in the Honda ad using the semiotics theory. Result obtained from the research is the overall meaning of visual and linguistic signs in 2017 Honda free ads.

Research on linguistic signs is always related to the research of meaning. This is based on interpretation in which it has its parameters, so the linguistic signs create a new meaning. The next research examines Barthes' semiotic text in Rahmawati (2017) which argues that the meaning of denotation and connotation cannot be separated from one another. The meaning of denotation is derived from the true meaning. In bahasa Indonesia, the meaning of a word is able to be defined within its formal level. After analyzing the meaning of denotation, the next step is understanding the context while determining the meaning of connotation. Barthes in Rahmawati (2017) explains that the new meanings of denotation or connotation could be produced if they are related to context and interpretation. Therefore, the research of meaning is still carried out until now because humans are inseparable from language and interpretation.

The next research is about linguistic devices in the orientation of body parts in Sundanese metaphors (Lyra, 2016). This research describes the metaphor produced by the body part in Sundanese. By using cognitive semantic metaphor and morphological theories, a linguistic device is produced. This device constructs a body part metaphor in the form of mono-morphemic (basic words) and polymorphisms (invented words, phrases, compound words, idioms, and clauses). Metaphors in the form of phrases, compound words, and idioms are built accordingly. This is formed by the construction of body part elements and other elements. Another interesting research that focused on slang-related languages is in social media, in which a variety of languages existed (Akyuwen, Sasabone, \& Tabelessy, 2020). This research examines the slang language on Facebook used by teenagers in Ambon City. The research results found are in the form of jargon, prokem, and colloquial.

In the research, the slang language used within the drug traffickers' organization will be explained. Also, a description of the determinants of slang selection will be provided to analyze the slang language in the group's communication. In sociolinguistics, the term language selection is known. To understand a language, the process of forming words and morphemes as the smallest parts of the language itself must be understood (Simpen, 2017). In addition, language selection is also used in social interactions with various language codes (Rokhman, 2013). Society will choose the available codes according to the factors that influence the codes. The choice of language in social interactions is influenced by various social factors. Evin-Tripp in Rokhman (2013) identifies four main factors as markers of a speaker's language choice in social interactions, which are (1) setting (time and place) and situation; (2) participants in the interaction; (3) conversation topics, and (4) interaction functions.

The first factor can be found, for example, the setting in family breakfasts, meetings at the office, wedding parties, bargaining at the market, or school. The second factor includes age, gender, occupation, socioeconomic status, and role in speech partners. The third factor can be the topic of interaction, such as work, children's success stories, actual events, or the topic of the price of goods in the market. The fourth factor is the interaction while offering information, requests, routine habits (greeting, apologizing, or saying thank you). According to Grosjean in Rokhman (2013), there are four factors that influence language choice in social interactions, namely participants, situations, discourse content, and interaction functions. The situation factor refers to the location or setting, the presence of the monolingual speaker, the level of formality, and the level of familiarity. The discourse content refers to the topic of conversation and the type of vocabulary. The interaction function refers to the aspects of raising status, creating social distance, removing someone from the conversation, or ordering or asking.

Based on the explanation of the factors that influence language choice in society, the research will discusses the reasons why drug users or dealers choose and use slang language in their communication and interactions. According to Saussure (Chandler, 2017), linguistic signs such as words are referred to as a 'signifier' and a 'signified'. The signifier is the form of the sign itself, while the signified is the concept of what it points to. Saussure in Chandler (2017) has stated that the signifier is the sound pattern, and the signified is a physical concept. Signifiers are interpreted as a material or physical form of a sign. It means something that can be seen, heard, touched, smelled, and felt. It can be seen in Figure 1.
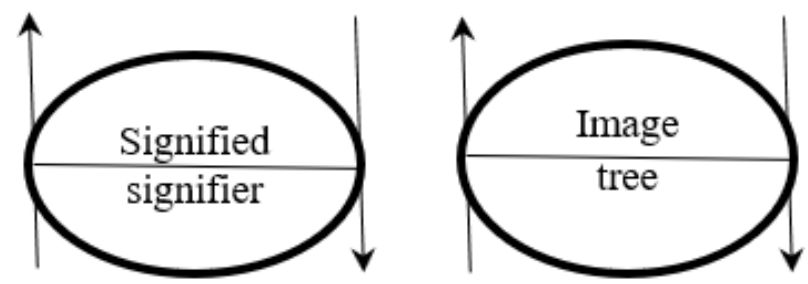

Figure 1 Signified and Signifier Image in Saussurean Model (Chandler, 2017)

In the Saussurean model, signs are based on the overall association results between the signifier and signified. The Saussure diagram in Figure 1 represents the relation between signifier and signified. The broken lines signify two elements of a sign. A linguistic example is a word 'open', which is a sign consisting of a signifier; the word open, and a signified concept; that the store is open for business (buying and selling) (Chandler, 2017).

A sign should identify the signifier and signified. The signifier is the same, for instance, the word 'on' may show a different signified or sign if it is placed on the button of a computer (as in "press to turn on the computer'). Many signifiers can also be interpreted as 


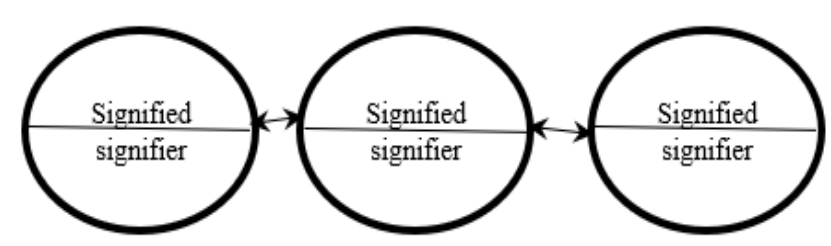

Figure 2 The Order of Signification (Chandler, 2017)

The 'value' of a sign depends on its relationship with other signs, as pictured in Figure 2. A sign is not absolutely based on contextual usage. Saussure in Chandler (2017) has analyzed the sign in a puzzle game. The value of each piece depends on its position on the board. It means the meaning indicated on the signified depends on the relationship between the two parts of the sign. The 'value' of the sign is determined based on the relationship between the sign and other signs in the whole system.

Types of meaning are divided into seven forms according to Umagandhi and Vinothini (2017), first is conceptual meaning or sense. This meaning comes from logic, which is a form of cognitive assessment. The meaning emerges from the parameters of true meaning that is known as the denotative meaning. Denotative meaning is understood by everyone and is believed to be form and meaning. Context is not needed because it is based on conceptual meaning, which can be referred to as the formal dictionary of each region or country. The second is connotative meaning. The meaning is formed based on the context, and it does not come from a formal dictionary. When communicating, language users sometimes want to hide the true meaning of the words or sentences that they want to convey. The meaning will be understood by the listener if both the speaker and the listener understand the meaning of the word conveyed. It can be inferred that to understand the connotative meaning; one requires context for getting the expected meaning. The third is social meaning. Community and social life patterns greatly affect the language being used. The meaning of a language is also influenced by social meaning. Society creates a habit or even a language tradition that can only be understood by the people of the same identity. In Indonesia, there are many local languages. Each region has a distinct language and culture that distinguish how they communicate with each other. Fourth is affective meaning. It is a picture or a gesture performed by a speaker or writer. In writing form, the writer will successfully touch the reader's feelings if the story uses the affective meaning. It means the feelings and attitudes of the writer are being conveyed to the reader. The language used often influences the listener's psychology. The speaker expects a reaction in the form of feelings and attitudes as an intent. The fifth is reflected meaning, which is communicated through feelings, similar to the expression. Reflective meaning is used to reflect something. The meaning achieved is being represented by a sign or symbol. To understand this meaning, people must understand the true meaning of a particular sign or symbol. All people who can understand this meaning will have the same feelings and thoughts. Sixth is collocative meaning, which is influenced by the environment. This type of meaning can mostly be found in the research, which is being described by the language used by the drug trafficking organization. This is part of the environment. A particular unhealthy environment may have a lot of secret codes used to communicate. Hence, this particular environment creates a new language or slang language that can only be understood by people in the group. The general public will not understand the purposes and objectives of the language being spoken. Therefore, the environment determines the formation of collocative meaning. Seventh is the thematic meaning, which is formed due to the message to be conveyed in communication has been arranged, and there is the emphasis from the speaker. In this case, the speaker has understood and arranged the words or sentences he/she wants to convey. The speaker will have the feedback based on the reaction and action of the listener so that this language often hypnotizes the listener. This language is often repeated by speakers of different listeners. The language patterns used are the same and cause the same reactions to other listeners.

\section{METHODS}

Based on the mapping of the West Sumatra Provincial National Narcotics Agency (Badan Nasional Narkotika Provinsi/BNNP), Padang city is the research site. This is a descriptive research with a qualitative approach. The research seeks to understand and explain the slang language used by drug dealers in trading transactions in Padang. The research produces descriptive data of slang language in the form of sentences, words, or phrases in Padang. The method used is an observation in which researchers are directly involved in obtaining data by oral interviews. The interview is conducted with a drug dealer who agrees to participate. This dealer carries out distributions and has connections with other associates.

There are three informants who are providing the data sources in the research. They are two ex-drug users and dealers in Ranah Parak Rumbio, which is one of the red drug zones in the South Padang subdistrict, and an anti-drug activist in Padang City. They are reliable as informants because they have had experience in drug trafficking for about twenty years. Data collection is carried out using an oral interview and note-taking technique. In this way, the researchers are able to document all utterances expressed by the former drug users. Usage of any new terms used in the drug trafficking community is recorded by the researcher in the slang language column.

The data are analyzed by using the identity method. There are several stages of data analysis in the research. The first is grouping utterances expressed by drug dealers based on words, phrases, or sentences 
following the Kamus Besar Bahasa Indonesia (KBBI), the Great Dictionary of the Indonesian Language. Next, the data are analyzed using equalizing and differentiating techniques, which are applied by replacing the word usage with ones suitable in KBBI. After getting the data in the form of slang language, the data are analyzed using Saussure's theory in Chandler (2017) about linguistic signs, consisting of signifier and signified. Finally, it is analyzed using connotation and denotation theory to determine new meanings according to the context.

The research results are presented using both informal and formal methods. Results presentation with informal data analysis is performed using commonly known words which can be easily understood by the general public. Formal presentation of data analysis is applied by using signs, symbols, and terms (Sudaryanto, 2015).

\section{RESULTS AND DISCUSSIONS}

The analysis is presented using tables to see the data in detailed descriptions. The data analyzed are the slang language used by a drug trafficking organization group of drug dealers and users in conducting drug trading transactions. The slang language is to be analyzed using Saussure's theory, which is the linguistic sign; the signifier and signified. Determining the signs requires a KBBI which is used to find the literal meaning of the words. Subsequently, to determine the signification of the sign, the context of the situation is needed. The context is the situation faced by the informants when this data is collected. Two informants share their experiences as a former drug user and drug dealer, also an informant who shares his/her activities as an anti-drug activist.

Slang language formation involves a shaping process. Warren divides it into three forms of formal innovation, which are word-formation, phoneme modification, and borrowing words. The wordformation process can be done through compounding, which is combining two words that have a more subtle meaning. This compounding word is to replace a less acceptable term or derivation, which is a wordformation process that produces new lexemes and produces different words from different paradigms or acronyms. A new formation is a short form of letters or syllables that are written and pronounced as acceptable words and has onomatopoeia, which is word forms that mimic a natural sound or its surroundings. Then, the process of modifying phonemes through back slang, which is replacing word forms by reversing the word order or rhythmic words. This includes the repetition of intermittent sounds. It is usually found at the end of adjacent rhyme lines, as well as phonemic replacement, which is the replacement of an impolite word sound form into a better sound and abbreviation. It is a shortened form of a word or sentence consisting of one or more letters and loan words, such as borrowing words from other foreign languages. Table
1 is the form of slang language that is divided by the process of its formation.

Table 1 Slang Form

\begin{tabular}{llrl}
\hline No & $\begin{array}{c}\text { Slang form } \\
\text { Category }\end{array}$ & N & \multicolumn{1}{c}{ Slang } \\
\hline 1 & Word & 8 & $\begin{array}{l}\text { Sprem, jokal, jokul, bokul, } \\
\text { kompor, alamat, kuda, } \\
\text { buka }\end{array}$ \\
2 & Affix & 6 & $\begin{array}{l}\text { Setengki, jokulan, ngunci, } \\
\text { ngelacak, penyakit, } \\
\text { peluncur }\end{array}$ \\
3 & Abbreviation & 2 & Mambo, pahe \\
4 & Phrase & 2 & Dua meter, tekapan sabu \\
5 & Back slang & 2 & Igab, wakas \\
\hline
\end{tabular}

The first slang in form 1 is sprem. The signifier is sprem. The signified of sprem is quarter gram, the mass and dose amount of an object. The order of signification of the sign sprem based on context is the dose to buy powdery drug measured by a quarter gram based on the drug's weight being sold or bought. The slang sprem has been chosen and used by speakers due to the situation and interaction factors. The occurring situation is the process of buying drugs with one of the dealers. Speakers use sprem because there is an interaction between the user and the dealer. The speaker wants to ask or to buy the drug with the amount or amount of drug he/she wants to use.

Slang form 2 is jokal. The signifier is jokal. The signified of jokal is roads or activities to rob, steal, or steal money to buy drugs. The order of signification of the sign jokal is based on the drugs context that is unusual action by a drug user to get money in order to fulfill the desire to buy drugs. Slang jokal is used to describe actions taken by drug users, which is to steal money. The factor of choosing that slang is based on the interaction function factor. It means drug users who want to steal money from the people or there is an opportunity to do so.

Slang form 3 is setengki. The signifier is setengki. The signified of setengki is a half of a gram, which is a mass or dose amount of an object. The order of signification of the sign setengki is based on the drugs context that is the dose to buy powdery drugs measured by half a gram based on the object's weight to be bought and sold. The use of slang setengki is due to situation and interaction factors. A situation is considered when a buyer wants to buy drugs from a dealer. They carry out the interactions, and the buyer states the amount or level of drugs based on needs. Because of these factors, the buyer uses slang setengki to determine the amount of drugs they want to buy.

Slang form 4 is jokul. The signifier is jokul. The signified of jokul is selling, the activity of offering something by expecting money in return. The order of signification of the sign jokul, based on the drugs 
context, is action taken by the dealer by offering drugs to be sold to the buyers. Slang jokul is used by drug dealers when selling their drugs. The selection of this slang is based on the participant's work and interaction function. The work of selling and distributing drugs to users is carried out by dealers. The slang jokul is the verb for selling. In this case, jokul is used because its function is to explain the interaction of selling drugs.

Slang form 5 is jokulan. The signifier is jokulan. The signified of jokulan is sales, objects offered for sale. The order of signification of the sign jokulan, based on the drugs context, is drugs (the goods) that are being sold and distributed by dealers to users. Slang jokulan is used because of the discourse's content. This vocabulary is used to describe the goods or drugs being sold. The slang jokulan is used in the sale and purchase of drugs.

Slang form 6 is mambo. The signifier is mambo. The signified of mambo is makan-bobok (eat and sleep), which is the activities that are carried out repeatedly, but it has a bad effect on the body. The order of signification of the sign mambo, based on the drug's context, is a term for poorly made crystal quality meth with side effects of eating and sleeping for a long time; therefore, it negatively impacts the body. Situation factors are applied to the use of slang mambo. The situation exists to disclose a drug overdose to the user. This situation occurs to the users who could not control themselves and used drugs excessively. Slang mambo is used to describe the habits of users who only eat and sleep after using drugs.

Slang form 7 is ngunci. The signifier is ngunci. The signified of ngunci is store, put in a safe place; therefore, it is not damaged or lost. The order of signification of the sign ngunci, based on the drugs context, is a term used by users to ask the availability of goods (the drugs) to other users. Slang ngunci is used by distributors and users because of the interaction function. The interactions occur when exchanging information about places or people who store and own drugs for sale. This information is usually asked by dealers to ensure the safety and secrecy of drug' storage.

Slang form 8 is bokul. The signifier is bokul. The signified of bokul is buy, get something through the exchange (payment) with money. The order of signification of the sign bokul, based on the drugs context, is actions taken by drug users to obtain goods (drugs) by buying it from the dealer. The factor of using slang bokul is caused by situation factors. A situation when a user buys drugs from a drug-dealer. To express their transaction, they use slang bokul.

Slang form 9 is ngelacak. The signifier is ngelacak. The signified of ngelacak is looking for or trying to get something. The order of signification of the sign ngelacak, based on the drugs context, is an action to find goods (the drugs). Slang ngelacak is used because of the interaction factor. An action is taken by users to find and dig up information on the whereabouts of drug dealers. The goal is to get and buy drugs.
Slang form 10 is penyakit. The signifier is penyakit. The signified of penyakit is security forces, individuals or legal institutions. The order of signification of the sign penyakit, based on the drugs context, is police, intelligence, the National Narcotics Agency (BNN), or citizens who are at war with drugs. Slang penyakit is caused by the content of the discourse. This means that drug users and dealers talk about the police, BNN, or people who are against drugs. Slang penyakit is often used when the police carry out the arrest and raid places where drugs are bought and sold. The users shout penyakit at other users to avoid the people if they do not want to deal with law enforcement.

Slang form 11 is kompor. The signifier is kompor. The signified of kompor is a tool that can produce heat. The order of signification of the sign kompor, based on the drugs context, is referring to a match or a drug burner. For the slang kompor, the selection factor is caused by the setting. The situation is applied when users need to use incendiaries to consume drugs. This is because there are types of drugs that first need to be burned. Therefore, the consumer needs advice called a drug burner.

Slang form 12 is igab. The signifier is igab. The signified of igab is asking, speaking so it can be given or get something. The order of signification of the sign igab, based on the drugs context, is ways used by drug users to request drugs from other users. The factor of using slang igab is due to the interaction function. The interaction occurs when a user asks another user for drugs or a user asks a dealer for drugs to be purchased.

Slang form 13 is alamat. The signifier is alamat. The signified of alamat is a person's name and place of residence. The order of signification of the sign alamat, based on the drugs context, is a term used to hide drugs. Slang alamat is used by the user or dealer due to the factor of place background. They use slang alamat to indicate the presence of drugs to store. The place where the drugs are stored does not only indicate a place but also describe the person who keeps them.

Slang form 14 is $k u d a$. The signifier is kuda. The signified of kuda is mammals, single hooves, commonly treated by people as vehicles (mounts, transportation) or vehicles puller. The order of signification of the sign $k u d a$, based on the drugs context, is courier, delivery person of drugs. The slang kuda selection factor is caused by the participant factor in the interaction. The participant in question is someone who works as a delivery person or intermediary between drug buyers and dealers. Slang kuda also means courier.

Slang form 15 is peluncur. The signifier is peluncur. The signified of peluncur is to glide, to move quickly. The order of signification of the sign peluncur, based on the drugs context, is designation for couriers, delivery goods (the drugs). The slang peluncur selection factor is caused by the participant in the interaction. The participant in question is someone who works as a delivery person or intermediary between drug buyers and dealers. Peluncur is also the slang used to dub jobs as a courier. 
Slang form 16 is buka. The signifier is buka. The signified of buka is selling, working. The order of signification of the sign buka, based on the drugs context, is sales, the term used whether the dealer sells goods (the drugs). The use of slang buka is caused by the interaction function factor. The interaction occurs when the user asks the dealer if he/she is selling or has stocks of drugs. This is known as asking the dealer for drug availability.

Slang form 17 is pahe. The signifier is pahe. The signified of pahe is saving package. Pahe is the abbreviation for paket hemat. The order of signification of the sign pahe, based on the drugs context, is an abbreviation used to indicate the price of drugs with the price of around two hundred thousand. The use of slang pahe is caused by the topic of conversation. The slang pahe is used to talk about the types of drugs that can be bought cheaply. The low price in question is below or around two hundred thousand rupiahs.

Slang form 18 is wakas. The signifier is wakas. The signified of wakas is sakaw. The order of signification of the sign wakas, based on the drugs context, is the term used to describe the state of the user which is in need of drugs accompanied by psychological and physical disorders. The use of slang wakas is caused by participant factors in the interaction, which is when the drug user has overdosed. This can cause mental and physical problems to drug users who abuse drugs beyond their capacity. The adverse effect caused by an overdose is known as wakas.

Slang form 19 is dua meter. The signifier is dua meter. The signified of dua meter is basic unit of length measurement. The order of signification of the sign dua meter, based on the drugs context, is a term signifying two hundred thousand rupiahs or the amount of money offered by the buyer. The use of slang dua meter is caused by the conversation topic factor, a conversation when a drug buyer offers money to the dealer for two hundred thousand rupiahs. This means that a two-meter hose is used for the topic of drug prices and as an indication of the amount of money in the transaction.

Slang form 20 is tekapan sabu. The signifier is tekapan sabu. The signified of tekapan sabu is crystal meth package. The order of signification of the sign tekapan sabu, based on the drugs context, is good (meth) packages that are delivered to be sent or sold. The use of slang tekapan sabu is caused by the conversational topic factor. Drug traffickers use slang tekapan sabu to describe the type of drug, such as sabu that has been stored in boxes and neatly wrapped. The wrapped crystal methamphetamine is known as a package that is ready to be delivered to the buyers.

After analyzing the process of forming slang words, finding out the linguistic signs from slang language, and determining the factors of language use, this research is expected to contribute to linguistic research, especially those that discuss slang, linguistic signs, and sociolinguistics. The results of the data analysis have explained that the process of forming slang words includes words (consists of 8 slangs), affixes (6 slangs), abbreviations ( 2 slangs), phrases (2 slangs), and back slang ( 2 slangs). Then, it also describes the factors of the language used, which are time and place background, a participant in interaction, conversation topic, and interaction function. These factors determine whether drug users and dealers choose to use slang to communicate.

\section{CONCLUSIONS}

Based on the data analysis described, it can be concluded that the slang language used by drug dealers and drug users has a different meaning. This difference indicates that utterances by these dealers cannot be understood by the general public; therefore, suspicions are not raised in regards to their activities. To understand the contextual meaning of words in slang language, a similar meaning is needed using KBBI. After finding the meaning of a particular word in KBBI, the context is also needed, which is represented by the drug trading transactions among drug dealers and users. This context is needed to get contextual meaning and understanding of the slang language used in carrying out transactions.

The result of the research indicates that slangs from the category of words, such as sprem, jokal, jokul, bokul, kompor, alamat, kuda, buka; slangs form category of affix, which are setengki, jokulan, ngunci, ngelacak, penyakit, peluncur; next, slangs form category of abbreviations are mambo, pahe; then, slangs form category of phrases are dua meter, tekapan sabu; and slangs form category of back slang are igab, wakas. The factors of language use are also considered, such as time and place of the background, a participant in the interaction, talking topic, and interaction function factors. These factors determine whether communication among drug users and dealers used slang language. After the research is completed, the future research planned is about the development of new vocabularies used in social media users, such as Instagram during the COVID-19 pandemic. The future research will focus on the forms of vocabularies that appeared during the COVID-19 pandemic on Instagram, the process of forming the vocabularies, and defining the meaning of those vocabularies, as well as its effect on society. This research is expected to be carried out in the future.

\section{ACKNOWLEDGEMENTS}

The authors want to express gratitude to the Ministry of Research and Technology/National Innovation Research Agency for funding this research. The funds provided to the author are used responsibly in completing this research. Furthermore, the authors also want to express gratitude to Ekasakti University and all the people who gave their directions, suggestions, and support so that the research was able to be conducted, and which has facilitated the continuity of this research. 


\section{REFERENCES}

Akyuwen, I., Sasabone, C., \& Tabelessy, N. (2020). Ragam bahasa gaul dalam media sosial Facebook remaja negeri Passo kota Ambon. Mirlam: Jurnal Pendidikan Bahasa dan Sastra Indonesia, 1(1), 93-102. https:// doi.org/10.30598/mirlamvol1no1hlm93-102.

Anisah, Z. (2019). Relevansi operasional bahasa dengan otak manusia. Stilistika: Jurnal Pendidikan Bahasa dan Sastra, 12(2), 187-196. https://doi.org/10.30651/ st.v12i2.2901.

Chandler, D. (2017). Semiotics: The basics ( $3^{\text {rd }}$ Ed). Abingdon: Routledge.

Devianty, R. (2017). Bahasa sebagai cermin kebudayaan. Jurnal Tarbiyah, 24(2), 226-245. http://dx.doi. org/10.30829/tar.v24i2.167.

Fadli, M. L., \& Suwandewi, A. (2019). Faktor yang berhubungan dengan kecenderungan penggunaan psikotropika zat adiktif (lem fox) pada remaja. Dinamika Kesehatan Jurnal Kebidanan dan Keperawatan, 10(2), 687-699. https://doi. org/10.33859/dksm.v10i2.505.

Hariyanto, B. P. (2018). Pencegahan dan pemberantasan peredaran narkoba di Indonesia. Jurnal Daulat Hukum, 1(1), 201-210. http://dx.doi.org/10.30659/ jdh.v1i1.2634.

Kinanthi, K., \& Nugroho, R. D. (2017). Makna iklan Honda merek freed keluaran tahun 2017 lewat tanda lingual dan tanda visual dengan kajian semiotika. Ayumi: Jurnal Budaya, Bahasa, dan Sastra, 4(2), 152-174. https://doi.org/10.25139/ayumi.v5i2.394.

Lyra, H. M. (2016). Peranti lingual metafora orientasional bagian tubuh dalam bahasa Sunda. Rika Bahasa: Jurnal Bahasa, Sastra, dan Pembelajarannya, 2(1), 42-47. https://doi.org/10.17509/rb.v2i1.8772.
Noermanzah. (2020). Bahasa sebagai alat komunikasi, citra pikiran, dan kepribadian. In Seminar Nasional Pendidikan Bahasa dan Sastra. Universitas Bengkulu. Bengkulu, $21^{\text {st }}$ October 2020. Pp. 306319. https://doi.org/10.31219/osf.io/ez6dk.

Rahmawati, I. (2017). Semiotik teks Roland Barthes dalam kehidupan kontemporer umat beragama mengenai fenomena padu padan kebaya. Tamaddun: Jurnal Kebudayaan dan Sastra, 17(2), 29-43. https://doi. org/10.19109/tamaddun.v17i2.2532.

Rokhman, F. (2013). Sosiolinguistik: Suatu pendekatan pembelajaran bahasa dalam masyarakat multikultural. Yogayakarta: Graha Ilmu.

Sari, C. P. (2018). Struktur tematik berita penyalahgunaan narkoba harian media Indonesia (Analisis wacana kritis Teun A. Van Dijk). FON: Jurnal Pendidikan Bahasa dan Sastra Indonesia, 12(1), 11-26. https:// doi.org/10.25134/fjpbsi.v12i1.1517.

Setyawan, I., \& Sulistyawati, S. (2019). Mewaspadai bahaya penyalahgunaan narkotika pada kalangan masyarakat desa Bandar Khalifah kecamatan Percut Sei Tuan. Seminar Nasional Hasil Pengabdian, 2(1), 451-456.

Simpen, I. W. (2015). Dinamika pembentukan kata Bahasa Indonesia. RETORIKA: Jurnal Ilmu Bahasa, 1(2), 319-330. https://doi.org/10.22225/jr.1.2.37.319-330.

Sudaryanto. (2015). Metode dan aneka teknik analisis bahasa: Pengantar penelitian wahana kebudayaan secara linguistis. Yogyakarta: Sanata Dharma University Press.

Suyatna, U. (2018). Evaluasi kebijakan narkotika di Indonesia. Sosiohumaniora, 20(2), 168-176. https:// doi.org/10.24198/sosiohumaniora.v20i2.16054.

Umagandhi, R., \& Vinothini, M. (2017). Leech's seven types of meaning in semantics. International Journal of Multidisciplinary Research and Development, 4(3), 71-72. 